Utah State University

DigitalCommons@USU

Economic Research Institute Study Papers

Economics and Finance

1996

\title{
Economies of Scale in Public Education: An Econometric Analysis
}

\author{
Kalyan Chakraborty \\ Utah State University \\ Basudeb Biswas \\ Utah State University \\ W. Cris Lewis \\ Utah State University
}

Follow this and additional works at: https://digitalcommons.usu.edu/eri

\section{Recommended Citation}

Chakraborty, Kalyan; Biswas, Basudeb; and Lewis, W. Cris, "Economies of Scale in Public Education: An Econometric Analysis" (1996). Economic Research Institute Study Papers. Paper 110.

https://digitalcommons.usu.edu/eri/110

This Article is brought to you for free and open access by the Economics and Finance at DigitalCommons@USU. It has been accepted for inclusion in Economic Research Institute Study Papers by an authorized administrator of DigitalCommons@USU. For more information, please contact digitalcommons@usu.edu.

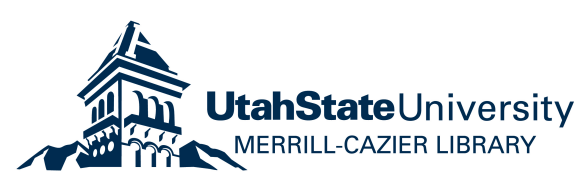


Economic Research Institute Study Paper

ERI \#96-45

ECONOMIES OF SCALE IN PUBLIC EDUCATION:

AN ECONOMETRIC ANALYSIS

by

KALYAN CHAKRABORTY

BASUDEB BISWAS

W. CRIS LEWIS

Department of Economics

Utah State University

Logan, UT 84322-3530

November 1996—revised March 1997 


\title{
ECONOMIES OF SCALE IN PUBLIC EDUCATION:
}

\section{AN ECONOMETRIC ANALYSIS}

\author{
Kalyan Chakraborty, Research Assistant \\ Basudeb Biswas, Professor \\ W. Cris Lewis, Professor \\ Department of Economics \\ Utah State University \\ Logan, UT 84322-3530
}

The analyses and views reported in this paper are those of the author. They are not necessarily endorsed by the Department of Economics or by Utah State University.

Utah State University is committed to the policy that all persons shall have equal access to its programs and employment without regard to race, color, creed, religion, national origin, sex, age, marital status, disability, public assistance status, veteran status, or sexual orientation.

Information on 'other titles in this series may be obtained from: Department of Economics, UMC 3530, Utah State University, Logan, Utah 84322-3530.

Copyright ( $\odot 1996$ by Kalyan Chakraborty, Basudeb Biswas, and W. Cris Lewis. All rights reserved. Readers may make verbatim copies of this document for noncommercial purposes by any means, provided that this copyright notice appears on all such copies. 


\title{
ECONOMIES OF SCALE IN PUBLIC EDUCATION: \\ AN ECONOMETRIC ANALYSIS

\author{
Kalyan Chakraborty, Basudeb Biswas, W. Cris Lewis
}

\begin{abstract}
The purpose of this paper is to investigate the sources of economies of scale in the production of public education. The relationship between the average cost of producing educational output and other school characteristics including the school and district size is estimated using a neoclassical cost function. The empirical analysis uses panel data from Utah school districts and estimates the function using the covariance and error component models after making necessary corrections for heteroscedasticity and autocorrelation. The evidence indicates that there are scale economies associated with school size but not district size.
\end{abstract}




\section{ECONOMIES OF SCALE IN PUBLIC EDUCATION: \\ AN ECONOMETRIC ANALYSIS}

\section{Introduction}

The consolidation, merger, and elimination of small rural school districts have been controversial issues in the United States for many years. Beginning at the end of the 19th century until the middle of the 20th century, the elimination of small rural school districts was mainly done to rationalize increased state control (Wiles 1994). The proconsolidation literature has proclaimed the virtues of consolidation by bringing about more effective schools by: increasing the tax base, quality of professional personnel, breadth of educational program, special services, transportation services, and by reducing overall educational costs per student (Butler and Monk 1985; and Ornstein 1989).

A strong and persuasive counterattack against consolidation started in the mid-1970s. It began with Summers and Wolfe (1975), who found higher achievement with smaller class size, and was followed by Sher (1988), who found that the efficiency and size of rural schools in Nebraska were unrelated to a student's performance. A comprehensive review by Monk (1990) suggests that any gain achieved by consolidation may be quickly exhausted when size interacts with socioeconomic variables. His view is that there is no evidence that increased size has resulted in comprehensive curriculum or any financial gain from economies of scale.

The majority of the proconsolidation literature rationalizes consolidation of school districts on the basis of saving cost due to economies of scale arising out of bigger size of the district. Contrary to the above, our earlier study (Lewis and Chakraborty 1996) showed that in the case of 
Utah, economies of scale exists at the school level rather than at the district level, and to capture economies of scale, average school size must be increased.

In our earlier study on economies of scale in the production of education in Utah, using panel data, we estimated the operating cost function of the school districts directly and indirectly (through an expenditure function) with fixed- and random-effect models. In this study, our objective is to reestimate the model assuming groupwise heteroscedasticity, correlation, and autocorrelation and verify if economies of scale exists at the school level.

This paper is organized as follows. The next section provides the background of our study. In section three, a formal model is developed in order to estimate the education cost function directly and indirectly. The data set is described in the next section, and then the statistical results are presented and discussed. Summary and concluding remarks are included in the final section.

\section{Background}

Economies of scale are defined as the reduction of the long-run average cost as the rate of output increases when the "state of the art" is given. The economies of scale theory incorporates its opposite, diseconomics of scale. Economics of scale and diseconomics of scale are referred to in this study as scale effects. Starting with the earliest work of Hirsch (1959), a considerable amount of research has been done on this topic in finding out two basic questions in the production of education:

(i) whether economies of scale exist in the production of education?, and

(ii) if they do exist, then at what level, school, or district? 
A scientific analysis of these issues is important in view of the general belief that consolidation of school districts always leads to lower cost per student. Most of the researchers are unanimous regarding the existence of economies of scale in the production of education. However, there are conflicting empirical results about the second issue. For example, Riew (1966) found economies of scale exist for high schools up to a level of 1,675 students from Wisconsin data (1960-61). However, his 1986 study found the larger economies of scale is in secondary schools compared to elementary schools. Cohn's (1968) study for high schools in Iowa also found existence of economies of scale up to 1,500 students. Using the data from public schools in New York state, Butler and Monk (1985) found that smaller school districts with 2,500 or fewer students show greater economies of scale than the larger school districts. Kumar's study (1983), using data from Canadian schools, shows the possibility of economies of scale by school consolidation. The study by Bee and Dolton 1985, ${ }^{1}$ using data from English schools, suggests a negative relationship between school size and average cost. Economies associated with district level is not very clear (see Callan and Santerre 1991; and Tholkes 1991).

Monk (1990) argues that consolidation has been pushed to such an extent that any further attempt to reduce the number of school districts may result in frustration and there will be only limited gains in productivity. However, he advocates the benefits of consolidation without eliminating school districts which includes the following strategies such as, regional service units, instructional technology, and shared administrative services, including proposals that all community social services are shared by neighboring districts. For example, Minnesota encourages this by providing up to 75 percent of the cost of shared secondary-school facilities and programs, and Iowa

${ }^{1}$ For a comprehensive literature review, please see Lewis and Chakraborty (1996). 
provides between 5 to 50 percent additional funding to local school districts that share course offerings, teachers, administrators, and school buildings (see Ornstein 1992).

Further, most of the earlier research on economies of scale in education production was done using cross-sectional data. In contrast, in this paper we try to answer those two questions mentioned above on economies of scale using panel data.

\section{Developing the Cost Function}

The model described below was specified by Downes and Pogue (1994) in the context of a study on estimating school-district cost functions using data from Arizona's elementary and secondary education systems. The authors started with the standard cost functions, the dual of neoclassical production function. The conventional specification is the log-linear relation between the total cost as the dependent variable and the quantity of output, input prices, measures of attributes of the community, and a stochastic disturbance term. The problem arises when public sector output cannot be measured satisfactorily. A method suggested by Chambers (1978), Bradbury et al. (1984), Ladd and Yinger (1989), and Ratcliffe, Riddle, and Yinger(1990) is that equilibrium output depends on some exogeneous variables, one of which is median income of families. Substituting these variables for output in the cost function, one gets what is termed as the expenditure function. Thus, two specifications are used: one is the cost function, which is derived directly, and the other is the indirect one, the expenditure function. The two methods of estimation are compared to show scale effects that exist both at the school and at the district level. The comparison is important because the two methods require different information and impose different degrees of structure. Direct estimation of the cost function requires measurement of public sector outputs, while identification 
of these parameters from an estimated expenditure function does not require that output be measured, but it does require specific assumptions about how government spending is determined.

Each community (i.e., school district) can be thought of as producing a vector of outputs, $Q$, using a vector of inputs, $X$. Hence, the underlying cost function in this production relationship for community $j$ at time $t$ is:

$$
C(.)=\operatorname{Min}_{\mathrm{X}} p X=c(Q, p, S),
$$

where $\mathrm{C}$ is the total cost, $\mathrm{p}$ is the vector of input prices, $\mathrm{S}$ is a vector of variables that measure attributes of the community or the school district that influence cost, including inputs supplied privately in the home such as parental training to their children at home. Given the data on outputs $(Q)$, input prices $(p)$, and community characteristics $(S)$, the cost function can be estimated directly, which will show the cost of producing each output vector dependent on input prices and the community-specific characteristics.

Since public sector output often cannot be measured satisfactorily, estimates of cost function from the reduced-form expenditure functions are widely used in the literature. This method assumes each community's output vector, $Q$, depends on a set of demand variables, $D$, as well as on each cost factor (i.e., on variables $\mathrm{p}$ and $\mathrm{S}$ ).

$$
Q=f(D, p, S) .
$$

Substituting (2) in (1) generates equation (3)

$$
C=c\lfloor f(D, p, S), p, S\rfloor=e(D, p, S) .
$$

The expenditure function for the community can be estimated without data on outputs. However, treating the coefficients of each cost factor (i.e., each element of $p$ and $S$ ) in the reduced-form expenditure function as an estimate of its cost of providing educational service 
underestimates their true effect on costs. If demand is cost-elastic (i.e., as cost of providing education increases its demand decreases), an increase in cost as a result of an environmental factor (i.e., an increase in the proportion of students needing special care) leads to a fall in expenditure. The coefficient of a cost factor in a reduced-form expenditure function thus reflects its effect on demand as well as its effect on costs. If cost function parameters are to be identified from estimation of the expenditure function, these effects must be separated (see Downes and Pogue 1994). Using exclusion restrictions on the variables $(D)$, which influence community demand not costs, identification can be achieved.

For estimation purposes, we assume ${ }^{2}$ the cost function can be written as the product of an output aggregate, $q(Q)$, and the per-unit cost of the aggregate, $h(p$, $S)$, i.e.,

$$
C=c(Q, p, S)=q(Q)^{*} h(p, S),
$$

where the form of the aggregate is technologically determined. This specific form leads to a log-linear specification of the cost function. The function, $h($.$) , shows the proportion by which the$ cost of a given package of services changes when $p$ and $S$ change. This specific cost function assumes that cost per unit of output aggregate $q(Q)$ are constant. If we assume the underlying production function is of the Cobb-Douglas type with constant returns to scale, then the cost function is linear in output. In this case, average cost, average variable cost, and the marginal cost function are all the same (see Varian 1992).

The specific log-linear form of equation (7), in terms of cost per student served for locality $\mathrm{j}$ at time t, may be written as:

\footnotetext{
${ }^{2}$ This does not restrict the assumption of variable return with respect to any individual output composing $Q$. Assuming a cost function of this form is equivalent to assuming a production function as homothetic (Varian 1992).
} 


$$
\ln C=L+\underset{i}{\alpha_{i}} \alpha_{i} \ln Q_{i}+\sum_{k} \psi_{k} \ln p_{k}+\sum_{k} \theta_{k} \ln S_{k}+\varepsilon
$$

where $Q_{i}$ are elements of output aggregate, $L$ is basically the intercept term and denotes the locality specific effect that reflects the temporary stable influences of omitted variables, and $\varepsilon$ is a white noise. These omitted variables may be the size of population of the community or the unobserved output being produced. In the first case, population affects cost through its effect on the productivity of the public sector inputs, such as teachers, while in the case of unobserved output being produced, the production cost of the unobserved output when added to the cost of observed outputs, cost of production differs between two locations. If the outputs, $Q_{i}$, can be measured, equation (8) can be estimated directly. If outputs cannot be measured directly, the cost function parameters can be estimated indirectly from an expenditure function.

In this study, following Downes and Pogue (1994), the expenditure function is estimated using median voter theory, under which each community provides the median preferred output (i.e., the median preferred output is that which is preferred by the voter with the median income). The median voter theory is widely used for the estimation of individual demand or public expenditure functions from cross-sectional studies (see Downes and Pogue 1994; and Barr and Davis 1966). Bergstrom and Goodman (1973) give this theory specific empirical content by showing that, subject to certain strong assumptions, majority rule implies that one can treat an observation of expenditure levels in a given jurisdiction as a point on the "demand curve" of a median income citizen of that community.

If it is assumed that $T_{m}$ is the median voter's share of taxes, and $Y_{m}$ is the median voter's income, then the equilibrium output, $Q$, will depend on the median voter's income, his share of the per-unit cost of output aggregate $\left(T_{m}{ }^{*} h(p, S)\right)$, and other characteristics of the median voter, $X_{m}$. 
Assuming the median voter's demand function for output $i$ is log-linear, it may be expressed

as:

$$
\begin{aligned}
\ln Q & =\delta_{i} X_{m}+\beta_{i} \ln Y_{m}+\ln \left\lfloor T_{m}^{*} h(p, S)\right\rfloor+\mu_{i} \\
\ln Q & =\delta_{i} X_{m}+\beta_{i} \ln Y_{m}+\ln T_{m}+\ln h(p, S)+\mu_{i}
\end{aligned}
$$

where $\mu_{\mathrm{i}}$ is a zero mean error which has identical, independent normal distribution. Substituting (7) into (5) gives the community expenditure function:

$$
\ln C=L^{*}+\beta^{*} \ln Y_{m}+\gamma_{i}^{*} \ln T_{m}+\underset{k}{\Sigma}\left(1+\gamma^{*}\right) \psi_{k} \ln p_{k}+\underset{k}{\Sigma}\left(1+\gamma^{*}\right) \theta_{k} \ln S_{k}+\varsigma
$$

where $\beta^{*}=\sum_{i} \alpha_{i} \beta_{i}, \quad \gamma^{*}=\sum_{i} \alpha_{i} \gamma_{i}, \quad L^{*}=L+X_{m}\left(\sum_{i} \alpha_{i} \delta_{i}\right)$. The error term, $\zeta$, represents the unobserved causal factors in demand and cost functions. It also accounts for any sort of lagged adjustments between desired and actual expenditure for a preferred output of the community that varies across location. The location-specific effect $(L)$ plays two roles. In cost function (5), it controls for the effect of output $(Q)$ and community-specific effects $(\mathrm{S})$ that are excluded and time invariant, and, in expenditure function (8), it does the same for the demand variables $(D)$ and the community-specific effects $(S)$. However, the magnitude of its effect on cost and expenditure functions differs.

The demand for educational output is directly affected by the median voter's share of the tax, hence, the coefficients of $T_{m}$ in equation (8) may be used to indirectly identify the parameters of the cost function $\left(\psi_{\mathrm{k}}\right.$ and $\left.\theta_{\mathrm{k}}\right)$ in equation (5). But we cannot measure the direct influence of output on cost, i.e., parameter $\alpha_{i}$ in equation (5), from equation (8). Estimates of parameters, $\gamma^{*}, \beta^{*}, \psi_{\mathrm{k}}$, and $\theta_{\mathrm{k}}$ can be identified from reduced-form estimates of equation (8). 


\section{The Data Set}

In this study, the cost of providing current educational services $(C)$ is measured by operating expenditure per student in the school district. Since there is no uniform measure of educational outputs $(Q)$, most studies of educational production relationships measure output by standardized achievement test scores, although some have used other qualitative measures such as student attitudes, school attendance rates, and college continuation or drop-out rates. However, because these scores were not available for all the years under study, this analysis uses the proportion of students graduating per 100 students per year in each school district as a fairly reasonable measure of educational output. An average 20-year teacher's salary having a B.A. degree is used as input prices $(p)$ in the cost and expenditure functions. In the expenditure function, the median voter's income is approximated as the per capita income of the population in the community. These are the demand variables $(D)$. Variables which account for the district and the student-specific characteristics $(S)$ includes total students in the district (district size), and average students per school (school size). Unlike our earlier study, we restricted the choice of our independent variables to graduates per 100 students, per capita income, teacher's salary, and school and district sizes in both cost and expenditure functions because we consider these to be the most important variables in estimating economies of scale. The explanatory variables in the cost function include graduates per 100 students as a measure of output, teacher's salary as a measure of input prices, and district and school sizes as measures of community-or district-specific characteristics. The expenditure function includes all explanatory variables stated above, except the measure of output, but it includes per capita income as a measure of demand. The coefficients on total students in the school district and 
average students per school indicate scale economies. A negative sign (positive) indicates economies (diseconomies) of scale. These data were collected from the various publications such as Utah Education Association (1983, 1988, 1993) and Utah State Office of Education (1983, 1988, 1993, and 1994).

The initial analysis focuses on per-student operating expenditures and the relation of each to size and growth of school districts. Table 1, which is reproduced from our earlier study, shows that as size increases, average spending per student decreases and vice versa. Generally, cost per student is about 40 percent lower in larger and growing districts than the smaller ones. An initial hypothesis is that average cost will be lowest in a large, growing district due to the operation of economies of scale, although the net effect of each component (i.e., size and growth), is not

Table 1. Average Operating Expenditure per Student and Size and Growth: Utah School Districts, 1982-83, 1987-88, and 1992-93

\begin{tabular}{|c|c|c|c|c|c|c|c|}
\hline \multirow[b]{2}{*}{ Students } & \multicolumn{2}{|c|}{$1982-83$} & \multicolumn{2}{|c|}{$1987-88$} & \multicolumn{2}{|c|}{$1992-93$} & \multirow[b]{2}{*}{$\begin{array}{l}\text { \% Change } \\
1982-93\end{array}$} \\
\hline & Districts & $\begin{array}{l}\text { Average } \\
\text { Operating } \\
\text { Expenditure }\end{array}$ & Districts & $\begin{array}{l}\text { Average } \\
\text { Operating } \\
\text { Exnenditure }\end{array}$ & Districts & $\begin{array}{l}\text { Average } \\
\text { Operating } \\
\text { Exnenditure }\end{array}$ & \\
\hline \multicolumn{8}{|l|}{ District Size: } \\
\hline$<1,000$ & 8 & $\$ 3,170$ & 7 & $\$ 3,389$ & 6 & $\$ 5,639$ & 43.8 \\
\hline $1,001-2,000$ & 7 & 2,129 & 7 & 2,743 & 7 & 3,814 & 44.2 \\
\hline $2,001-5,000$ & 9 & 2,164 & 8 & 2,741 & 9 & 3,890 & 44.3 \\
\hline $5,001-10,000$ & 7 & 1,991 & 6 & 2,476 & 6 & 3,394 & 41.3 \\
\hline $10,001-25,000$ & 5 & 1,999 & 8 & 2,409 & 6 & 3,281 & 39.1 \\
\hline$>25,000$ & 4 & 1,858 & 4 & 2,191 & 6 & 3,129 & 40.6 \\
\hline Median & & $\$ 2,060$ & & $\$ 2,536$ & & $\$ 3,594$ & \\
\hline \multicolumn{8}{|c|}{ District Growth Rate: } \\
\hline$<0 \%$ & 6 & $\$ 2,909$ & 6 & $\$ 3,624$ & 6 & $\$ 5,198$ & 44.0 \\
\hline $0-10 \%$ & 8 & 2,485 & 8 & 3,104 & 8 & 4,277 & 41.9 \\
\hline $10-20 \%$ & 12 & 2,094 & 12 & 2,467 & 12 & 3,474 & 39.7 \\
\hline$>20 \%$ & 14 & 2,044 & 14 & 2,505 & 14 & 3,377 & 39.5 \\
\hline
\end{tabular}

Source: Utah State Office of Education (1983, 1988, 1993). 
determined by these data nor are the effects of quality accounted for. It is hypothesized that there are economies of scale in both school and district sizes and, therefore, the coefficients on district size and growth should be negative. Also, it is expected that there are scale economies associated with the average size of schools in the district. Finally, it is hypothesized that the demand measures should have a positive effect on expenditures.

\section{Parameter Estimation and Analysis of Results}

Examination of the raw data suggests that the variance may be different for 40 time series due to districtwise variation in the scale of all variables in the model. Hence, we would expect groupwise heteroscedasticity. We do not expect timewise autocorrelation. This is simply because each school district is observed at five-year intervals and, thus, any disturbance that occurred in one year may not be serially correlated with the observations in the fifth or tenth year. However, we may expect cross-sectional correlation of the disturbances across districts. This is likely because the macroeconomic factors that affect these districts affect all of them to varying degrees.

The estimation of the parameters follows two distinct stages. In the first stage, we tested the hypothesis about the basic assumption concerning the behavior of the stochastic disturbance term $(\varepsilon)$. That is, we tested for timewise heteroscedasticity, timewise autocorrelation, groupwise heteroscedasticity, and cross-sectional autocorrelation. In the second stage, we corrected for these violations and reestimated the model and applied the Hausman test to determine which of the models, fixed or random effect, would be appropriate in this case. Three procedures used in the first

stage are: (i) pooled regression, (ii) groupwise heteroscedastic regression, and (iii) groupwise heteroscedastic and cross-sectionally autocorrelated regression. 
Procedure 1. Initially we used White's test for heteroscedasticity and the Durbin Watson test for autocorrelation separately for cost and expenditure functions on the pooled regression. While we do not find any evidence of autocorrelation in the cases of both functions, the expenditure function proved to be heteroscedastic. The results from the OLS estimation of the cost and expenditure functions corrected for the heteroscedastic covariance matrix are reported in Table 2. All coefficients for both functions have expected signs and, except for district size, all are significantly different from zero at the 5 percent or below level.

Procedure 2. Treating all cross-sectional units in each year under study as a group, we tested the cost and the expenditure functions for groupwise heteroscedasticity. Using the Lagrange multiplier, Wald, and likelihood ratio tests, we failed to reject the null hypothesis of

\section{Table 2. Pooled Regression with 120 Observations}

\begin{tabular}{lcc}
\hline \hline & & \\
Variables & Cost Function & Expenditure Function \\
\hline & & \\
Constant & -15.321 & -12.575 \\
& $(-12.594)^{*}$ & $(-8.141)^{*}$ \\
Ln (graduates per 100 students) & -0.095 & \\
& $(-1.933)^{*}$ & 0.196 \\
Ln (per capita income) & & $(3.091)^{*}$ \\
Ln (20 years teacher's salary) & 1.941 & 1.578 \\
& $(20.215)^{*}$ & $(10.433)^{*}$ \\
Ln (students per district) & -0.027 & -0.022 \\
& $(-1.735)$ & $(-1.814)$ \\
Ln (students per school) & -0.248 & -0.260 \\
Variance $\left(\varepsilon^{\prime} \varepsilon\right.$ ) & $(-7.139)^{*}$ & $(-7.303)^{*}$ \\
R-Squared & 1.8084 & 1.6693 \\
& .8452 & .8571 \\
\hline
\end{tabular}

t-statistics are shown in parentheses.

*-indicates that the estimated coefficient is significant at or below the 5 percent level. 
homoscedasticity in both cost and expenditure functions. The LM test for autocorrelation suggests that there is no yearwise autocorrelation in both functions. Yearwise least square estimates of the parameters (i.e., 40 cross-sectional units observed in years 1982, 1987, and 1992) are reported in Table 3, and yearwise heteroscedastic and nonautocorrelated feasible generalized least square (FGLS) results are reported in Table 4. In Table 3, all coefficients in both functions have expected signs. The coefficients on the variable teacher's salary for 1987 and 1992 and school size for all years are significantly different from zero at the 5 percent or below level for both functions. However, the coefficients on per-capita income in the expenditure function and graduates per 100 students in the cost function are insignificant. As expected, the magnitude of the coefficients in Table 4 are almost the same as in Table 2, because there is no groupwise heteroscedasticity or yearwise autocorrelations.

Table 3. Yearwise Least Square Estimate

\begin{tabular}{|c|c|c|c|c|c|c|}
\hline \multirow[b]{2}{*}{ Variables } & \multicolumn{3}{|c|}{ Cost Function } & \multicolumn{3}{|c|}{ Expenditure Function } \\
\hline & 1982 & 1987 & 1992 & 1982 & 1987 & 1992 \\
\hline Constant & $\begin{array}{c}-3.384 \\
(-0.622)\end{array}$ & $\begin{array}{c}-8.499 \\
(-1.698)\end{array}$ & $\begin{array}{c}-4.286 \\
(-0.873)\end{array}$ & $\begin{array}{c}-0.280 \\
(-0.005)\end{array}$ & $\begin{array}{c}-6.893 \\
(-1.363)\end{array}$ & $\begin{array}{c}-5.272 \\
(-1.054)\end{array}$ \\
\hline Ln (graduates/10,0 students) & $\begin{array}{c}-0.051 \\
(-0.459)\end{array}$ & $\begin{array}{c}-0.101 \\
(-1.591)\end{array}$ & $\begin{array}{c}-0.183 \\
(-1.469)\end{array}$ & & & \\
\hline Ln (per capita income) & & & & $\begin{array}{c}0.237 \\
(2.676)^{*}\end{array}$ & $\begin{array}{c}0.103 \\
(1.035)\end{array}$ & $\begin{array}{c}0.036 \\
(0.353)\end{array}$ \\
\hline Ln (20 yrs teacher's salary) & $\begin{array}{c}0.473 \\
(1.112)\end{array}$ & $\begin{array}{c}1.415 \\
(3.612)^{*}\end{array}$ & $\begin{array}{c}1.114 \\
(3.000)^{*}\end{array}$ & $\begin{array}{c}0.581 \\
(1.491)\end{array}$ & $\begin{array}{c}1.197 \\
(2.964)^{*}\end{array}$ & $\begin{array}{c}1.131 \\
(2.923)^{*}\end{array}$ \\
\hline Ln (students per district) & $\begin{array}{c}-0.006 \\
(-0.226)\end{array}$ & $\begin{array}{c}-0.018 \\
(-0.675)\end{array}$ & $\begin{array}{c}-0.017 \\
(-0.653)\end{array}$ & $\begin{array}{c}0.005 \\
(0.181)\end{array}$ & $\begin{array}{c}-0.029 \\
(-1.122)\end{array}$ & $\begin{array}{c}-0.016 \\
(-0.593)\end{array}$ \\
\hline Ln (students per school) & $\begin{array}{l}-0.276 \\
(-4.388)^{*}\end{array}$ & $\begin{array}{c}-0.266 \\
(-4.663)^{*}\end{array}$ & $\begin{array}{c}-0.268 \\
(-4.836)^{*}\end{array}$ & $\begin{array}{c}-0.325 \\
(-5.391)^{*}\end{array}$ & $\begin{array}{c}-0.233 \\
(-4.442)^{*}\end{array}$ & $\begin{array}{c}-0.253 \\
(-4.394)^{*}\end{array}$ \\
\hline Variance $\left(\varepsilon^{\prime} \varepsilon\right)$ & 0.5100 & 0.5274 & 0.4505 & 0.4259 & 0.5488 & 0.4765 \\
\hline R-squared & 0.7163 & 0.7579 & 0.7900 & 0.7631 & 0.7481 & 0.7778 \\
\hline
\end{tabular}

$\mathrm{t}$-statistics are shown in parentheses.

*-indicates that the estimated coefficient is significant at or below the 5 percent level.

Values of $\varepsilon^{\prime} \varepsilon$ in parentheses are based on the pooled slope estimator. 
Table 4. FGLS Estimate of Yearwise Heteroscedastic, Nonautocorrelated Disturbance

\begin{tabular}{lcc}
\hline \hline Variables & Cost Function & Expenditure Function \\
\hline & & \\
Constant & -15.376 & -12.537 \\
& $(-12.841)^{*}$ & $(-9.540)^{*}$ \\
Ln (graduates per 100 students) & -0.095 & \\
& $(-2.013)^{*}$ & 0.200 \\
Ln (per capita income) & & $(3.858)^{*}$ \\
Ln (20 yrs teacher's salary) & 1.945 & 1.572 \\
& $(20.593)$ & -0.022 \\
Ln (students per district) & -0.027 & $(-1.473)$ \\
Ln (students per school) & $(-1.780)$ & -0.262 \\
& -0.249 & $(-8.090)^{*}$ \\
LM statistics & $(-7.364)^{*}$ & 56.76 \\
\hline
\end{tabular}

$\mathrm{t}$-statistics are shown in parentheses.

*-indicates that the estimated coefficient is significant at or below the 5 percent level.

Procedure 3. Treating $n$ cross-sectional units ( $i=1,2,3 \ldots 40$ school districts) observed at each time period $(t=1,2,3)$, cost and expenditure functions are tested for groupwise heteroscedasticity and cross-sectional correlation. Using OLS parameter estimates, we obtain the estimates of $\sigma_{i}^{2}$ for each school district. These estimates suggest that the variances do not differ substantially across school districts for the cost function, while it does for the expenditure function. We used LM, Wald, and LR tests for heteroscedasticity. While LM statistics are based on pooled regression, the Wald statistics for the common estimate of $\sigma^{2}$ used the total sum of squared GLS residuals, and LR statistics are based on the FGLS estimates. For the cost function, we failed to reject the null hypothesis of homoscedasticity, and the expenditure function is found to be heteroscedastic by the Wald and LR tests and homoscedastic by the LM test. We reestimated the expenditure function allowing for heteroscedasticity, as shown in the FGLS results reported in 
Table 5. Column 1 of that table reports groupwise heteroscedastic regression with nonautocorrelated disturbance.

Allowing correlation of the disturbances across the school districts, we extend the model for cross-sectional correlation, which is $E\left[\varepsilon_{i} \varepsilon_{j}^{\prime}\right]=\sigma_{i j} I$, but we continue to assume that observations are uncorrelated across time. To test the hypothesis that the off-diagonal elements of $\Sigma$ are zero (i.e., there is no correlation across units), we used the LM test, which has a $\chi^{2}$ distribution, with $n(n-1) / 2$ degrees of freedom. In the cost function we found that there is no such correlation across school districts but in the expenditure function, we failed to reject the null hypothesis of nonautocorrelation. Hence, allowing cross-sectional correlation across units, we used different AR(1) processes for each school district and reestimated the expenditure function. From the initial least-square estimates, the

Table 5. Groupwise Heteroscedastic FGLS Estimate of Expenditure Function

\begin{tabular}{llll}
\hline \hline Variables & $\begin{array}{l}\text { Groupwise Hetero., } \\
\text { Correlated, and } \\
\text { Nonautocorrelated } \\
\text { Disturbances. }\end{array}$ & $\begin{array}{l}\text { Groupwise Hetero., } \\
\text { Group Specific, and } \\
\text { Autocorrelation }\end{array}$ & $\begin{array}{l}\text { Groupwise Hetero. } \\
\text { Correlated, and } \\
\text { Group Specific } \\
\text { Autocorrelation }\end{array}$ \\
& & & \\
& & & \\
Constant & -17.8020 & -17.9200 & -18.540 \\
& $(-30.022)^{*}$ & $(-39.926)^{*}$ & $(-61.230)^{*}$ \\
Ln (per capita income) & -0.0041 & -0.0050 & -0.0068 \\
& $(-0.835)$ & $(-0.832)$ & $(-2.347)^{*}$ \\
Ln (20 yrs teacher's salary) & 2.1064 & 2.1310 & 2.1852 \\
& $(44.212)^{*}$ & $(56.073)^{*}$ & $(85.977)^{*}$ \\
Ln (students per school district) & -0.0325 & -0.0263 & -0.0266 \\
& $(-4.058)^{*}$ & $(-2.911)^{*}$ & $(-3.732)^{*}$ \\
Ln (students per school) & -0.2066 & -0.2457 & -0.2561 \\
& $(-10.051)^{*}$ & $(-10.463)$ & $(-12.776)^{*}$ \\
& & & \\
\hline
\end{tabular}

$\mathrm{t}$-statistics are shown in parentheses.

*-indicates that the estimated coefficient is significant at or below the 5 percent level. 
district-specific autocorrelations and variances of $u_{\mathrm{it}}$ and $\varepsilon_{\mathrm{it}}$, based on the transformed data, are estimated. The FGLS parameter estimates, based on the transformed data, are reported in column 3 of Table 5. Finally, the estimates are recomputed using the full model with cross-sectional covariance giving the results shown in column 4 of Table 5.

The results suggest that the direct estimation of the cost function generates mostly insignificant coefficients on the output measure, except in Table 4, but it has the right sign (i.e., negative). In the expenditure function, the coefficient on income generally is significant and positive, except in Table 5, where it is negative and insignificant. This suggests that a one-dollar increase in the median voter's income would increase the expenditure by more than one dollar.

The positive and highly significant coefficients on salary imply that additional spending on resources will be productive. The negative and highly significant coefficients on the variable average students per school in all the tables suggests strong economies of scale exist at the school level. This suggests that the per-student cost decreases as enrollment increases. In fact, when school size is regressed along with the district size, the latter becomes insignificant.

In the second stage of our estimation process, the parameters of the cost and expenditure functions are estimated using the fixed-effect and random-effect models (also known as covariance model and error-component model, espectively). In the case of the covariance model, the specific characteristic of a cross-sectional unit is a parameter (i.e., separate intercept term for its own); for the error-component model, the specific characteristic of a cross-sectional unit is a normally distributed random variable (see Kmenta 1986).

The results are reported in Table 6. The fixed- and random-effect estimates differ mainly in the case of input price (i.e., teacher's salary), where the coefficients differ by more than one standard 
Table 6. Estimates of the Cost and Expenditure Function Parameters Dependent Variable: Ln (operating expenditure per student)

\begin{tabular}{|c|c|c|c|c|}
\hline \multirow[b]{2}{*}{ Variables } & \multirow{2}{*}{$\frac{\text { Cost Function }}{\text { Fixed }}$} & \multicolumn{3}{|c|}{ Expenditure Function } \\
\hline & & Random & $\overline{\text { Fixed }}$ & Random \\
\hline Constant & & $\begin{array}{c}-14.2250 \\
(-10.782)^{*}\end{array}$ & & $\begin{array}{c}-12.3200 \\
(-8.868)^{*}\end{array}$ \\
\hline Ln (graduates/100 students) & $\begin{array}{c}-0.1312 \\
(-2.484)^{*}\end{array}$ & & & \\
\hline Ln (per capita income) & & & $\begin{array}{r}0.0986 \\
(1.669)\end{array}$ & $\begin{array}{c}0.1819 \\
(3.634)^{*}\end{array}$ \\
\hline Ln (20 yrs. teacher's salary) & $\begin{array}{c}1.1301 \\
(5.223)^{*}\end{array}$ & $\begin{array}{c}1.8537 \\
(17.954)^{*}\end{array}$ & $\begin{array}{c}1.1799 \\
(5.374)^{*}\end{array}$ & $\begin{array}{c}1.5668 \\
(12.486)^{*}\end{array}$ \\
\hline Ln (students per district) & $\begin{array}{c}-0.0178 \\
(-0.999)\end{array}$ & $\begin{array}{c}-0.0317 \\
(-2.148)^{*}\end{array}$ & $\begin{array}{r}-0.0307 \\
(-1.791)\end{array}$ & $\begin{array}{c}-0.0276 \\
(-1.882)^{*}\end{array}$ \\
\hline Ln (students per school) & $\begin{array}{l}-0.2455 \\
(-6.686)^{*}\end{array}$ & $\begin{array}{c}-0.2371 \\
(-7.427)^{*}\end{array}$ & $\begin{array}{l}-0.2265 \\
(-6.303)^{*}\end{array}$ & $\begin{array}{l}-0.2495 \\
(-7.926)^{*}\end{array}$ \\
\hline R-squared & $\begin{array}{r}0.8452 \\
15703\end{array}$ & 0.8439 & $\begin{array}{l}0.9239 \\
2147\end{array}$ & \\
\hline Hausman test statistic & 16 & & & \\
\hline
\end{tabular}

t-statistics are shown in parentheses.

*-indicates that the estimated coefficient is significant at or below the 5 percent level.

The Hausman statistic is based on fixed- vs. random-effect results from the corresponding models.

deviation. The estimated effects of other variables are similar in fixed- and random-effect specifications. The large values of Hausman test statistics for random- versus fixed-effect models also suggest the use of a fixed-effect model. In both cost and expenditure functions, we fail to reject the null hypothesis that the district-specific effects are fixed against the alternative hypothesis of random effect based on the F-test. The sign of the coefficients in both cost and expenditure functions for fixed-effect models are as expected, and they are highly significant. These results confirm our earlier findings that the average school size is more important than district size as far as economies of scale is concerned. 


\section{Summary and Conclusion}

The results of this analysis confirm our earlier results which showed economies of scale exists at the individual school level, hence, consolidation of schools will reduce costs per student substantially. The most important determinants of the cost of public education in Utah are average school size, teacher salary, and per capita income of the district population.

As the coefficient of district size is not significantly different from zero at the 5 percent or below level, we conclude that economies of scale is not important at the district level. Thus, consolidation of school districts, in an attempt to reduce per-unit cost, may not be successful unless average school size can be increased at the same time. Further, there often is political resistance to such consolidation of districts; if average school size is the driving force behind cost reduction, it may be possible to consolidate schools within a district and capture most of the scale economies.

\section{References}

Barr, J., and O. Davis. 1966. "An Elementary Political and Economic Theory of the Expenditures of Local Governments.” Southern Economics Journal 33:149-296.

Bee, M., and P.J. Dolton. 1985. “Costs and Economies of Scale in U.K. Private Schools.” Applied Economics 17:281-290.

Bergstrom, T., and R. Goodman. 1973. "Private Demand for Public Goods." American Economic Review 63:286-296.

Bradbury, K.L., H.F. Ladd, M. Perrault, A. Reschovsky, and J. Yinger. 1984. "State Aid to Offset Fiscal Disparities Across Communities.” National Tax Journal 37:151-70.

Butler, R.J., and D.H. Monk. 1985. "The Cost of Public Schooling in New York State: The Role of Scale and Efficiency in 1978-79." The Journal of Human Resources 20(Summer): 361-381.

Callan, S.J., and R.E. Santerre. 1990. “The Production Characteristics of Local Public Education: A Multiple Product and Input Analysis.” Southern Economic Journal 57(October):468-80. 
Chambers, J.G. 1978. "Educational Cost Differentials and the Allocation of State Aid for Elementary and Secondary Education.” Journal of Human Resources 13(Fall):459-81.

Cohn, E. 1968. "Economies of Scale in Iowa High School Operations." Journal of Human Resources 3(Fall):422-34.

Downes, T.A., and T.F. Pogue. 1994. "Adjusting School Aid Formulas for the Higher Cost of Educating Disadvantaged Students.” National Tax Journal (March):89-110.

Hirsch, W.Z. 1959. "Expenditure Implications of Metropolitan Growth and Consolidation." Review of Economics and Statistics 41(August):232-41.

Kiesling, H.J. 1966. "Measuring a Local Government Service: A Study of School Districts in New York State." Review of Economics and Statistics 49(August):356-67.

Kmenta, J. 1987. Elements of Econometrics. (2nd ed.) New York: Macmillan Publishing Co.

Kumar, R.C. 1983. "Economies of Scale in School Operation: Evidence from Canada." Applied Economics 15:323-40.

Ladd, H.F., and J. Yinger. 1989. "Ailing Cities: Fiscal Health and the Design of Urban Policy." New York: The Johns Hopkins University Press.

Lewis, W.C., and K. Chakraborty. 1996. "Scale Economies in Public Education." The Journal of Regional Analysis and Policy 26:23-35.

Monk, D.H. 1990. "The Organization and Reorganization of Rural Schools.” In A. DeYoung (ed.), The Rural Education in America, New York: Garland Publishing.

Ornstein, A.C. 1989. "Controversy Over Size Continues.” School Administrator (April):42-3.

Ornstein, A.C. 1992. "Rural/Urban School Districts: Trends in Consolidation and Decentralization." Clearing House 65(5):322-6.

Ratcliffe, Kerri, B. Riddle, and J. Yinger. 1990. "The Fiscal Condition of School Districts in Nebraska: Is Small Beautiful?" Economics of Education Review 9:81-99.

Riew, J. 1966. "Economies of Scale in High School Operations." Review of Economics and Statistics 48(8, August):280-7.

- 1986. "Scale Economies, Capacity Utilization, and School Costs: A Comparative Analysis of Secondary and Elementary Schools." Journal of Education Finance 11(Spring): 433-46. 
Sher, J. 1988. Class Dismissed: Examining Nebraska's Rural Education Debate. Lincoln, Nebraska: Nebraska Rural Community School Assoc.

Summers, A., and B. Wolfe. 1975. "Which School Resources Help Learning?” Business Review (February).

Tholkes, R.J. 1991. "Economies of Scale in Rural School District Reorganization." Journal of Education Finance 16(Spring):497-514.

Utah Education Association. Various years. Teacher Salary Schedules, Research Bulletin 28(2, January). Salt Lake City, Utah.

Utah State Office of Education. Various years. Annual Report of the State Superintendent, 1982-88. Salt Lake City, Utah. September. - 1993. Summary of Statistical and Financial Data of the Utah State Superintendent of Public Instruction, 1992-93. Salt Lake City, Utah, September. . 1994. Utah Statewide Testing Program. Salt Lake City, Utah, January.

Varian, H.R. 1992. Microeconomic Analysis. (3rd ed.) New York: W.W. Norton \& Co.

Wiles, D.K. 1994. "What is Useful Policy Information in School Consolidation Debates?" Journal of Education and Finance 19(Winter):292-318. 